\title{
EVALUASI KETERCAPAIAN STANDAR PENJAMINAN MUTU PENELITIAN DI PROGRAM STUDI D3 MESIN OTOMOTIF UNIVERSITAS MUHAMMADIYAH MAGELANG DENGAN METODE INDEKS
}

\author{
Oleh \\ Muji Setiyo, Budi Waluyo, Saifudin, Bagiyo Condro Purnomo, \\ Suroto Munahar, Noto Widodo, Retno Rusdjijati \\ Universitas Muhammadiyah Magelang \\ setiyo.muji@ummgl.ac.id
}

Diterima 6 Desember 2017, direvisi 21 Januari 2018, diterbitkan 28 Pebruari 2018

\begin{abstract}
In the past decade, the general method for measuring the performance of research and scientific publications in a Study Program at a Higher Education is by the Rough Value (Nilai Kasar, NK) calculated per three years. This value is derived from the accreditation instrument. In fact, the calculation of the performance of research and scientific publications with NK cannot represent an annual performance. Therefore, this paper presents a new method for calculating research and scientific publications performance with an index (IP-PS and IPub-PS), which is calculated annually. An example of quality measurement practice in the Automotive Diploma Program of Universitas Muhammadiyah Magelang. As a result, calculations with IP-PS and IPub-PS are more likely to present real conditions per year than using NK.
\end{abstract}

Keywords: research performace, publication performance, IP-PS, IPub-PS

\section{PENDAHULUAN}

Pasca terbitnya Permendikbud Nomor 49 tahun 2014 yang direvisi dengan Permenristekdikti Nomor 44 tahun 2015, Standar Nasional Pendidikan Tinggi (SN-Dikti) secara jelas mengintegrasikan standar pendidikan, standar penelitian, dan standar pengabdian kepada masyarakat dengan penjelasan yang sangat detail yang masingmasing standar terdiri dari 8 standar turunan (Kemenristekdikti, 2015).
Standar nasional penelitian diturunkan menjadi standar hasil penelitian, standar isi penelitian, standar proses penelitian, standar penilaian penelitian, standar peneliti, standar sarana dan prasarana penelitian, standar pengelolaan penelitian, dan standar pendanaan dan pembiayaan penelitian. Review hubungan antar standar untuk satu siklus penelitian (inputproses-output-tindak lanjut) tersebut disajikan dalam Gambar 1 (Muji Setiyo, 2017b). Yang menarik dari setiap pernyataan standar, bahwa 
definisi standar dalam Permenristekdikti Nomor 44 tahun 2015 tersebut adalah kriteria minimal. Untuk itu, secara tidak langsung Peraturan Menteri tersebut memberikan perintah kepada "Audience" atau subjek yang menjalankan setiap standar mutu untuk berupaya melampaui, bukan sekedar memenuhi.

Di Universitas Muhammadiyah Magelang, dan seluruh Perguruan Tinggi Muhammadiyah/ 'Aisyiyah (PTM/A) di Indonesia, selain harus melampaui kriteria standar minimal yang dipersyaratkan Pemerintah, juga wajib untuk melaksanakan standar yang ditetapkan oleh Majelis Diktilitbang PP Muhammadiyah yang tertuang dalam Pedoman Sistem Penjaminan Mutu Internal Perguruan Tinggi Muhammadiyah/ 'Aisyiyah (SPMI-PTM/A).

Program Studi Mesin Otomotif Universitas Muhammadiyah Magelang, sebagai bagian dari PTM/A, telah mengimplemantasikan sistem penjaminan mutu penelitian dibawah koordinasi Badan Penjaminan Mutu (BPM) dan Lembaga Penelitian, Pengembangan dan Pengabdian kepada Masyarakat (LP3M) yang tidak hanya memenuhi standar nasional, namun sesuai dengan Pedoman SPMI PTM/A. Kedalaman dan keluasan materi penelitian selain harus mencakup materi kajian khusus untuk kepentingan nasional dan harus memuat prinsipprinsip kemanfaatan, kemutahiran, dan mengantisipasi kebutuhan masa depan, juga harus sesuai dengan visi program studi dalam upaya mewujudkan keunggulan program studi.

Untuk itu, sebagai program studi yang memiliki visi unggul dalam "Teknologi Kendaraan Efisien”, Program Studi Mesin Otomotif Universitas Muhammadiyah Magelang menyusun roadmap penelitian yang mengacu pada Agenda Riset Nasional (DRN, 2016) dan Rencana Induk Penelitian Universitas Muhammadiyah Magelang. Roadmap penelitian dan implementasinya selama 3 periode $2015-2017$ disajikan dalam Gambar 2.

Kemudian, dalam Sistem Informasi Kinerja Penelitian dan Pengabdian kepada Masyarakat (SI-KPPM) pada URL: http:// dosen.ummgl.ac.id/ selama 2015-2017 telah tercatat kegiatan penelitian yang dihasilkan dosen-dosen program studi sebanyak 19 judul, dengan 11 judul mendapatkan pembiayaan dari DRPM melalui skema INSINAS, PDP, dan PDD serta 8 judul sisanya mendapatkan pembiayaan dari internal kampus melalui skema

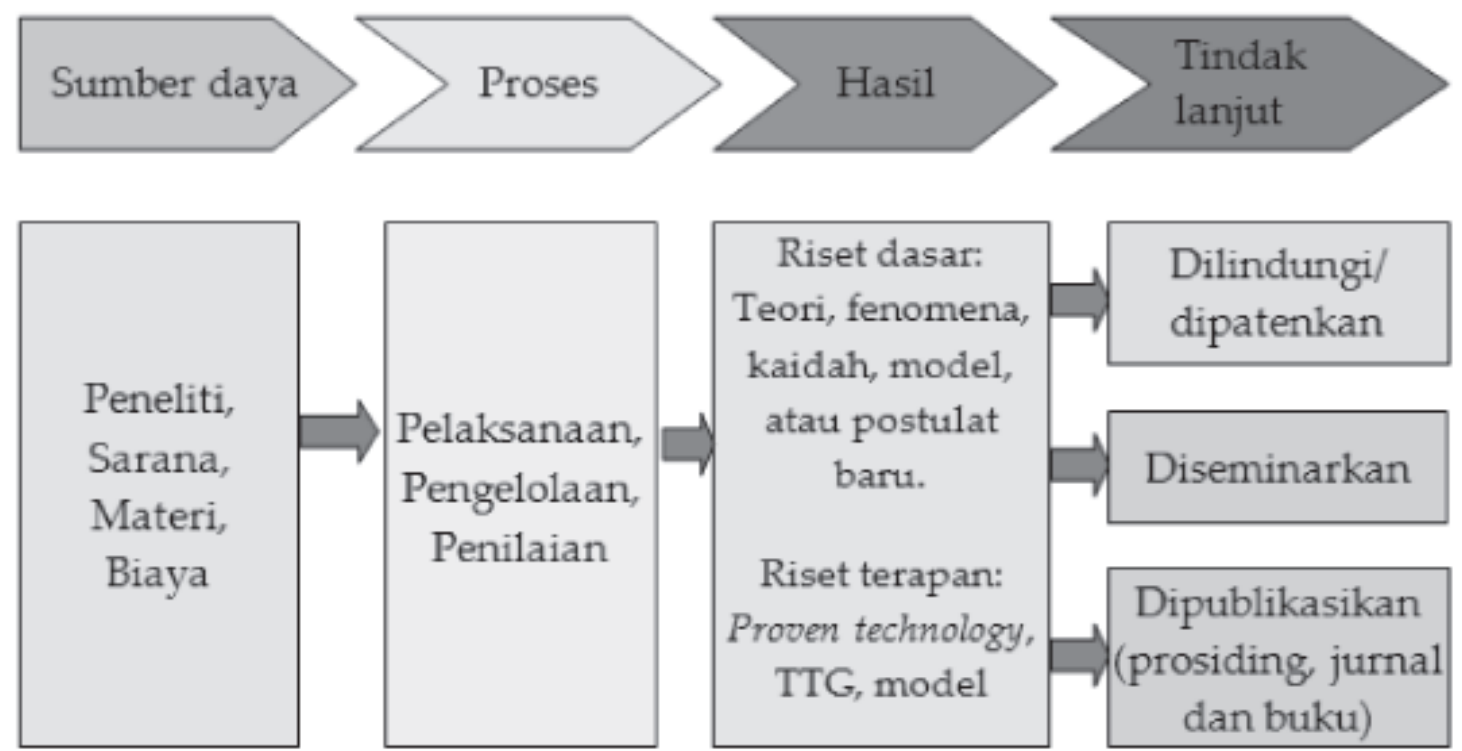

Gambar 1. Manajemen pencapaian standar hasil penelitian 


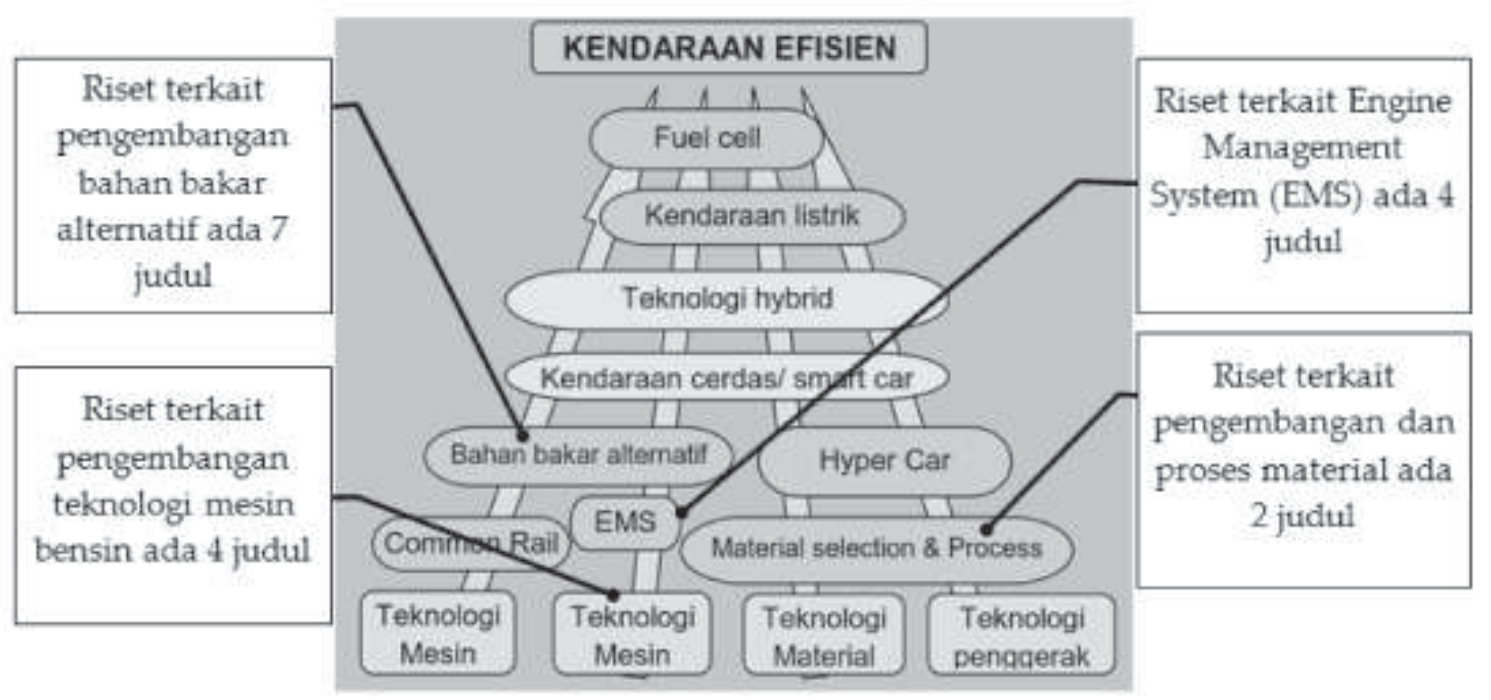

Gambar 2. Roadmap penelitian Program Studi Mesin Otomotif Universitas Muhammadiyah Magelang 2014-2024

Penelitian Revitaslisasi Visi Institusi (PRVI). Dari 19 judul tersebut, 17 judul sesuai roadmap penelitian (Gambar 2), sisanya merupakan riset multidisipliner yang kurang sesuai dengan roadmap penelitian program studi dan telah menghasilkan 13 publikasi nasional, 13 publikasi internasional, 5 paten, dan 2 buku dengan data sebagaimana disajikan pada Tabel 1. Namun, dalam artikel ini dibatasi pada analisis untuk penelitian dan publikasi karen belum semua paten telah berstatus "Granted".

Dari Tabel 1, perlu dilakukan asessment ketercapaian penelitian dan luarannya menggunakan instrumen audit mutu eksternal (instrumen akreditasi) untuk mengetahui posisi ketercapaian standar penelitian program studi terhadap SN-Dikti. Namun demikian, indikator penelitian dan luarannya dalam instrumen akreditasi menggunakan skala 3 tahunan. Untuk itu, artikel ini menyajikan hasil asessment ketercapaian penelitian dan luarannya menggunakan instrumen akreditasi yang dimodifikasi untuk bisa mengukur ketercapaian tahunan.

\section{PEMBAHASAN}

\subsection{Indikator Kinerja Penelitian}

Indikator untuk mengukur ketercapaian jumlah penelitian menggunakan skalainstrumen akreditasi dihitung dengan persamaan (1) sebagai berikut.

$$
N F=\frac{4 n_{a}+2 n_{b}+n_{c}}{f}
$$

Dimana, $n_{a}$ adalah jumlah penelitian dengan biaya luar negeri yang sesuai bidang ilmu selama 3 tahun, $n_{b}$ adalah jumlah penelitian dengan biaya dari Kemenristekdikti dan institusi dalam negeri di luar Kemenristekdikti yang sesuai bidang ilmu selama tiga tahun terakhir, $n_{c}$ adalah jumlah penelitian dengan biaya dari $\mathrm{PT} /$ sendiri yang sesuai bidang ilmu selama tiga tahun, dan $f$ adalah jumlah dosen tetap yang bidang keahliannya sesuai dengan program studi. Dengan persamaan (1), SN-Dikti dinyatakan terpenuhi jika nilai NK e" 1 . Untuk memudahkan analisis per tahun dalam siklus SPMI, persamaan (1) diatas diubah dari NK (nilai kasar) menjadi Indeks Penelitian Program 
Tabel 1. Review publikasi Program Studi Mesin Otomotif Universitas Muhammadiyah Magelang tahun 2015-2017

\begin{tabular}{|c|c|c|c|}
\hline No & Peneltiti & Judul Publikasi & Kategori \\
\hline 1. & $\begin{array}{l}\text { (Waluyo, Condro, \& } \\
\text { Saifudin, 2015) }\end{array}$ & $\begin{array}{l}\text { Penggunaan berbagai jenis filter pada oil } \\
\text { catch tank untuk perbaikan performansi } \\
\text { mesin old vehicle }\end{array}$ & $\begin{array}{l}\text { Prosiding } \\
\text { nasional }\end{array}$ \\
\hline 2. & $\begin{array}{l}\text { (Saifudin, Sutoyo, } \\
\text { Malau, \& Iswanto, } \\
2015)\end{array}$ & $\begin{array}{l}\text { Karakterisasi mekanis dan fisis lapisan } \\
\text { diamond-like carbon (DLC) dengan } \\
\text { teknik plasma assisted chemical vapor } \\
\text { deposition (PACVD) pada permukaan } \\
\text { tool steel HSS }\end{array}$ & $\begin{array}{l}\text { Prosiding } \\
\text { nasional }\end{array}$ \\
\hline 3. & $\begin{array}{l}\text { (Muji Setiyo, } \\
\text { Soeparman, } \\
\text { Wahyudi, \& Hamidi, } \\
\text { 2016) }\end{array}$ & $\begin{array}{l}\text { A simulation for predicting potential } \\
\text { cooling effect on LPG-fuelled vehicles }\end{array}$ & $\begin{array}{l}\text { Prosiding } \\
\text { internasional }\end{array}$ \\
\hline 4. & $\begin{array}{l}\text { (Fahmi \& } \\
2015)\end{array}$ & $\begin{array}{l}\text { Pengaruh campuran ethanol pada laju } \\
\text { korosi tangki bahan bakar }\end{array}$ & $\begin{array}{l}\text { Prosiding } \\
\text { nasional }\end{array}$ \\
\hline 5. & $\begin{array}{l}\text { (Munahar, } \\
\text { Triwiyatno, } \\
\text { Setiawan, 2015) }\end{array}$ & $\begin{array}{l}\text { Strategi peningkatan model air to fuel } \\
\text { ratio (AFR) dan brake control system } \\
\text { pada mesin bensin }\end{array}$ & $\begin{array}{l}\text { Prosiding } \\
\text { nasional }\end{array}$ \\
\hline 6. & $\begin{array}{l}\text { (Triwiyatno, } \\
\text { Sinuraya, Setiawan, } \\
\text { \& Munahar, 2016) }\end{array}$ & $\begin{array}{l}\text { Smart controller design of ait to fuel ratio } \\
\text { (AFR) and brake control system on } \\
\text { gasoline engine }\end{array}$ & $\begin{array}{l}\text { Prosiding } \\
\text { internasional }\end{array}$ \\
\hline 7. & $\begin{array}{l}\text { (Waluyo \& Saifudin, } \\
\text { 2016) }\end{array}$ & $\begin{array}{l}\text { Performance of SI engine at various of } \\
\text { oil catch tank filter materials }\end{array}$ & $\begin{array}{l}\text { Jurnal } \\
\text { Internasional }\end{array}$ \\
\hline 8. & $\begin{array}{l}\text { (Muji } \quad \text { Setiyo, } \\
\text { Waluyo, Husni, \& } \\
\text { Karmiadji, 2016) }\end{array}$ & $\begin{array}{l}\text { Characteristics of } 1500 \mathrm{cc} \text { LPG fueled } \\
\text { engine at various of mixer venturi area } \\
\text { applied on tesla a-100 LPG vaporizer }\end{array}$ & $\begin{array}{l}\text { Jurnal } \\
\text { Internasional }\end{array}$ \\
\hline 9. & $\begin{array}{l}\text { (Saifudin, Munahar, } \\
\text { \& Khusaeni, 2016) }\end{array}$ & Perilaku inhibitor korosi pada radiator & $\begin{array}{l}\text { Jurnal } \\
\text { nasional }\end{array}$ \\
\hline 10. & $\begin{array}{l}\text { (M. Setiyo, } \\
\text { Soeparman, Hamidi, } \\
\text { \& Wahyudi, 2016) }\end{array}$ & $\begin{array}{l}\text { Techno-economic analysis of liquid } \\
\text { petroleum gas fueled vehicles as public } \\
\text { transportation in Indonesia }\end{array}$ & $\begin{array}{l}\text { Jurnal } \\
\text { Internasional }\end{array}$ \\
\hline 11. & $\begin{array}{l}\text { (Muji } \quad \text { Setiyo, } \\
\text { Waluyo, Anggono, } \\
\text { \& Husni, 2016) }\end{array}$ & $\begin{array}{l}\text { Performance of gasoline/LPG bi-fuel } \\
\text { engine of manifold absolute pressure } \\
\text { sensor (MAPS) variations feedback }\end{array}$ & $\begin{array}{l}\text { Jurnal } \\
\text { Internasional }\end{array}$ \\
\hline 12. & $\begin{array}{l}\text { (Widiyanto } \\
\text { Munahar, 2016) }\end{array}$ & $\begin{array}{l}\text { Key-less Automatic Lock System using } \\
\text { RFID \& Smartphone }\end{array}$ & $\begin{array}{l}\text { Prosiding } \\
\text { nasional }\end{array}$ \\
\hline 13. & $\begin{array}{l}\text { (Rusdjijati, Setyo, } \\
\text { Sugiarto, \& Raliby, } \\
2016 \text { ) }\end{array}$ & $\begin{array}{l}\text { Unsafety Behaviour Pekerja di Industri } \\
\text { Kayu Lapis yang Berpotensi } \\
\text { Menyebabkan Kecelakaan Kerja }\end{array}$ & $\begin{array}{l}\text { Prosiding } \\
\text { nasional }\end{array}$ \\
\hline
\end{tabular}

Evaluasi Ketercapaian Standar Penjaminan Mutu Penelitian di Program Studi D3 Mesin Otomotif Universitas Muhammadiyah Magelang Dengan Metode Indeks | Muji Setiyo, dkk. 
14. (Muji Setiyo, Temperature distribution of R-134a Jurnal

Saifudin, Purnomo, through aluminum and PTFE expansion Internasional

Waluyo, \& valve on automotive air conditioning

Ramadhan, 2017) applications

15. (Waluyo, Wardana, The role of molecule cluster on the Jurnal

Yuliati, \& Sasongko, azeotrope and boiling points of isooctane- Internasional 2018) ethanol blend

16. (Munahar \& Setiyo, AFR modeling of efi engine based on Jurnal 2017) engine dynamics, vehicle dynamics, and nasional transmission system

17. (M. Setiyo, Characteristic of LPG compositions in the Soeparman, Hamidi, fuel line during discharging process Internasional \& Wahyudi, 2017a)

18. (Muji Setiyo \& AFR and fuel cut-off modeling of LPGMunahar, 2017)

fueled engine based on engine,

Jurnal transmission, and brake system using fuzzy logic controller (FLC)

19. (M. Setiyo, Cooling effect characteristics of a $1 / 2$ cycle Soeparman, Hamidi, refrigeration system on an LPG fuel

Jurnal \& Wahyudi, 2017b) system

20. (Muji

Setiyo, The alternative way to drive the Internasional Soeparman, automobile air-conditioning, improve Internasional Wahyudi, \& Hamidi, performance, and mitigate the high 2018) temperature: a literature overview

21. (M.

Setiyo, Modeling of deceleration fuel cut-off for LPG fuelled engine using fuzzy logic

Jurnal Internasional

\section{Munahar,}

Triwiyatno,

\& controller

Setiawan, 2017)

22. (Purnomo \& Setiyo, Karakteristik sistem refrigerasi kompresi 2017) uap dengan refrigerant campuran musicool 134 - CO2

23. (Muji Setiyo, Studi numerik: efek perubahan komposisi Waluyo, Purnomo, LPG terhadap energy delivery pada spark Munahar, \& ignition (S.I.) engine Setyawan, 2017)

24. (Munahar, Setiyo, Karakteritik linearization system dan data Purnomo, \& Aman, acqusition pada pengembangan engine 2017) control unit-(ECU) pada EFI engine dengan drive train

Jurnal Internasional

Jurnal nasional

Prosiding nasional 25. (Purnomo, Widodo, Karakteristik emisi gas buang kendaraan
Munahar, Setiyo, \& berbahan bakar LPG untuk mesin bensin

Prosiding Waluyo, 2017) single piston 
Studi (IP-PS).

$$
\text { IPPS }=\frac{4 n_{z}+2 n_{\text {b }}+n_{c}}{f}
$$

Karena standar NK yang memenuhi SNDikti e" 1, maka di program studi dibuat IPPS e" 0,4 agar jika IP-PS terpenuhi, SN-Dikti terlampaui. Jumlah penelitian di Program Studi D3 Otomotif Universitas Muhammadiyah Magelang adalah $4 \times 2 n_{b}+2 n_{c}(2015), 5 \times 2 n_{b}+3 n_{c}$ (2016) dan $2 \times 2 n_{b}+3 n_{c}(2017)$. Sehingga, hasil pengukuran IP-PS nya adalah 1,43 (2015), 1,86 (2016), dan 1,0 (2017) dengan nilai baseline 1,43 pada tahun 2014. Trend capaian terhadap nilai standar IP-PS Program Studi D3 Otomotif Universitas Muhammadiyah Magelang disajikan dalam Gambar 3.

\subsection{Indikator Kinerja Publikasi}

Sama halnya dengan kinerja penelitian, indikator untuk mengukur ketercapaian jumlah publikasi menggunakan skala instrumen akreditasi dihitung dengan persamaan (3) sebagai berikut.

$$
N F=\frac{4 n_{a}+2 n_{b}+n_{c}}{f}
$$

Dimana, $n_{a}$ adalah jumlah artikel ilmiah tingkat internasional yang sesuai bidang ilmu selama 3 tahun, $n_{b}$ adalah jumlah artikel tingkat nasional atau buku yang sesuai bidang ilmu selama tiga tahun terakhir, $n_{c}$ adalah jumlah jumlah artikel tingkat lokal yang sesuai bidang ilmu selama tiga tahun, $\operatorname{dan} f$ adalah jumlah dosen tetap yang bidang keahliannya sesuai

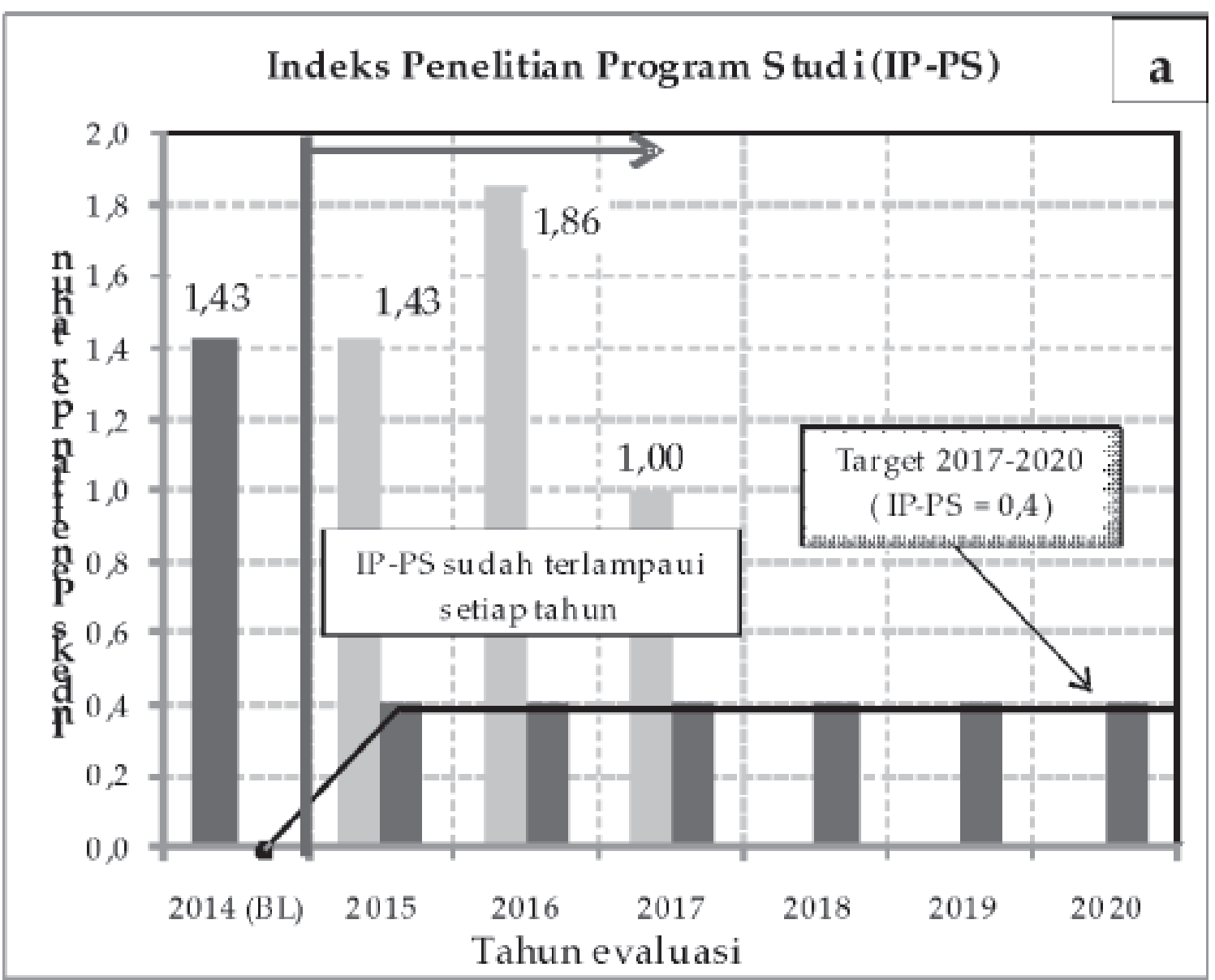

Gambar 3. IP-PS Program Studi D3 Otomotif Universitas Muhammadiyah Magelang tahun 2015-2017 


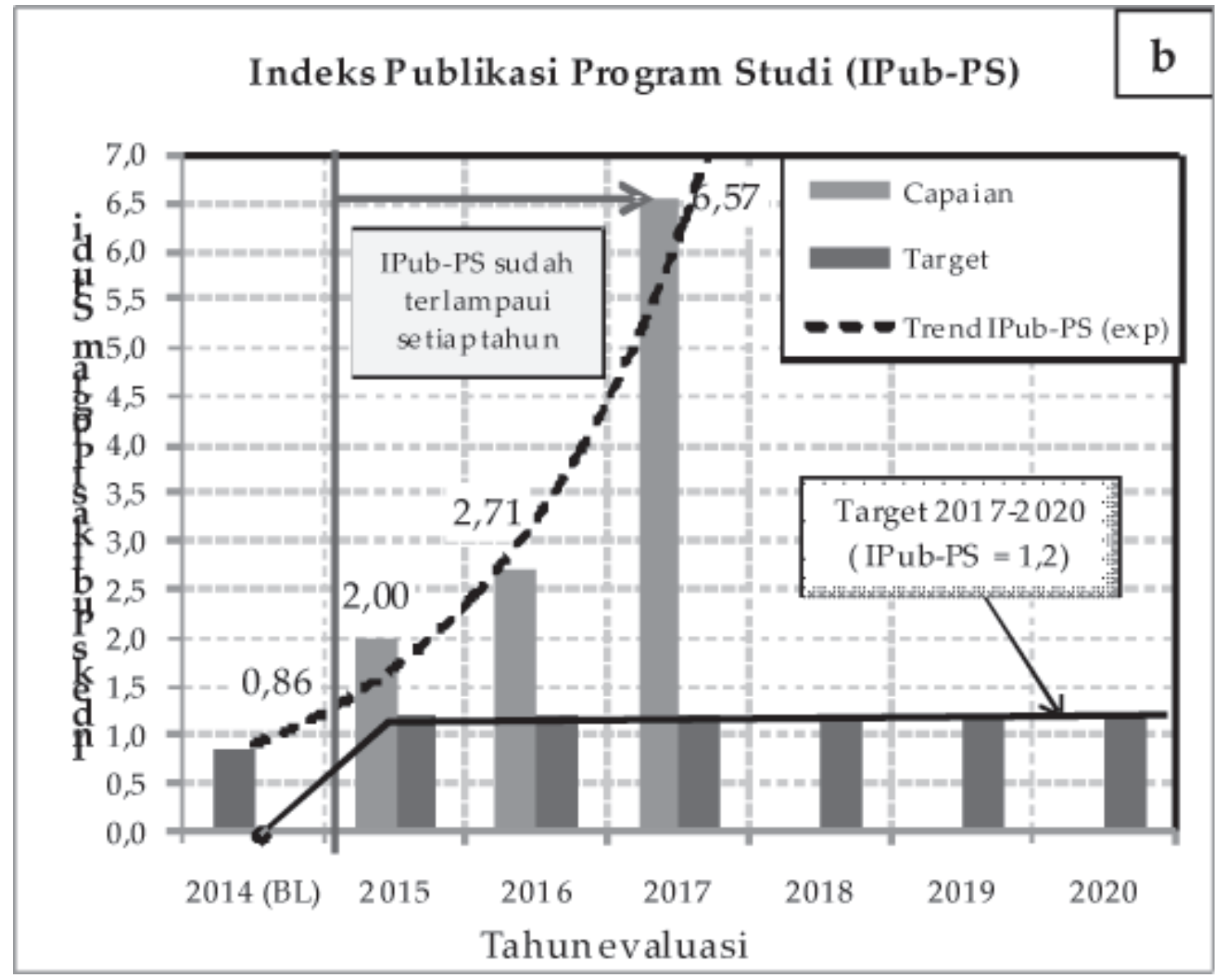

Gambar 4. IPub-PS Program Studi D3 Otomotif Universitas Muhammadiyah Magelang tahun 2015-2017

dengan program studi. Dengan persamaan (3), SN-Dikti dinyatakan terpenuhi jika nilai NK e" 3. Untuk memudahkan analisis per tahun dalam siklus SPMI, persamaan (3) diatas diubah dari NK (nilai kasar) menjadi Indeks Publikasi Program Studi (IPub-PS).

$$
\text { IPub } P S=\frac{4 n_{a}+n_{j}+n_{c}}{f}
$$

Karena standar NK yang memenuhi SNDikti e" 3, maka di program Studi dibuat IPubPS e" 1,2 agar jika IPub-PS terpenuhi, SNDikti terlampaui. Jumlah publikasi di Program Studi D3 Otomotif Universitas Muhammadiyah Magelang adalah $7 \times 2 n_{b}(2015), 4 \times 4 n_{a}+3 n_{b}$ (2016) dan $7 \times 4 n_{a}+2 \times 9 n_{b}$ (2017). Sehingga, hasil pengukuran IPub-PS nya adalah 2,0 (2015), 2,71 (2016), dan 6,57 (2017) dengan nilai baseline 0,86 pada tahun 2014 . Trend capaian terhadap nilai standar IPub-PS Program Studi D3 Otomotif Universitas Muhammadiyah Magelang disajikan dalam Gambar 4.

\section{SIMPULAN}

Dari hasil analisis ketercapaian sasaran mutu penelitian dan publikasi di Program Studi D3 Mesin Otomotif Universitas Muhammadiyah Magelang diperoleh data bahwa model assesment menggunakan Indeks Penelitian Program Studi (IP-PS) dan Indeks Publikasi (Pub-PS) Program Studi lebih menggambarkan kondisi riil tahunan di Program Studi dibandingkan menggunakan skala Nilai Kasar (NK). Dalam tiga tahun terakhir, 
pelaksanaan evaluasi dan pengendalian mutu di Program Studi menjadi lebih mudah dengan IP-PS dan IPub-PS dibandingkan dengan menggunakan NK. Tentu, dalam evaluasi dan pengendalian, hanya penelitian dan publikasi yang sesuai dengan roadmap penelitian yang diperhitungkan. Sebagai kesimpulan, IP-PS dan IPub-PS sangat menjanjikan untuk dipertimbangkan sebagai indikator ketercapaian standar penjaminan mutu internal di Program Studi untuk mengontrol ketercapaian standar tahunan.

\section{DAFTAR PUSTAKA}

DRN. (2016). Agenda Riset Nasional 20162019. Jakarta: Dewan Riset Nasional.

Fahmi, L., \& Setiyo, M. (2015). Effect of ethanol blend on corrosion rate of fuel tank (original: Pengaruh campuran ethanol pada laju korosi tangki bahan bakar). In Semnastek (pp. 1-6). Jakarta: Fakultas Teknik Universitas Muhammadiyah Jakarta. Retrieved from jurnal.ftumj.ac.id/ index.php/semnastek

Kemenristekdikti. Peraturan Menteri Riset, Teknologi, dan Pendidikan Tinggi Republik Indonesia No. 44 Tahun 2015 (2015). Indonesia.

Munahar, S., Rusdjijati, R., Purnomo, T. A., \& Hidayati, L. L. A. (2017). Perancangan Mesin Perajang Kerupuk dan Kulit Ikan Guna Meningkatkan Produktivitas Kerja Pengrajin Produk Ikan. In The 6th URECOL (pp. 39-44). Magelang: Universitas Muhammadiyah Magelang. Retrieved from http://journal.ummgl.ac.id/ index.php/urecol/article/view/1565/678

Munahar, S., \& Setiyo, M. (2017). AFR Modeling of EFIEngine Based on Engine Dynamics, Vehicle Dynamics, and Transmission System. Jurnal Teknik Mesin, 7(1), 21-29. http://doi.org/http:// dx.doi.10.21063/JTM.2017.V7.20-29
Munahar, S., Setiyo, M., Purnomo, B. C., \& Aman, M. (2017). Karakteritik Linearization System Dan Data Acqusition Pada Pengembangan Engine Control Unit( ECU ) Pada EFI Engine. In The 6th URECOL (pp. 21-26). Magelang: Universitas Muhammadiyah Magelang. Retrieved from http://journal.ummgl.ac.id/ index.php/urecol/article/view/1532/853

Munahar, S., Triwiyatno, A., \& Setiawan, J. D. (2015). Strategi Peningkatan Model Air To Fuel Ratio (AFR) dan Brake Control System Pada Mesin Bensin. In Seminar Nasional Perkembangan Riset dan Teknologi dibidang Industri ke - 21. Yogyakarta: Universitas Gadjah Mada.

Purnomo, B. C., \& Setiyo, M. (2017). Karakteristik sistem refrigerasi kompresi uap dengan refrigerant campuran musicool 134 - CO2. Jurnal Teknologi, 9(2). http:/ /doi.org/DOI: https://dx.doi.org/10.24853/ jurtek.9.2.57-64

Purnomo, B. C., Widodo, W., Munahar, S., Setiyo, M., \& Waluyo, B. (2017). Karakteristik Emisi Gas Buang Kendaraan Berbahan Bakar LPG untuk Mesin Bensin Singke Piston. In The 6th URECOL (pp. 7-12). Magelang: Universitas Muhammadiyah Magelang. Retrieved from http://journal.ummgl.ac.id/index.php/ urecol/article/view/1601/849

Primayana, K. H. (2016). MANAJEMEN SUMBER DAYA MANUSIA DALAM PENINGKATAN MUTU PENDIDIKAN DI PERGURUAN TINGGI. Jurnal Penjaminan Mutu, 1(2), 7-15.

Rusdjijati, R., Setyo, S., Sugiarto, A., \& Raliby, O. (2016). Unsafety Behaviour Pekerja di Industri Kayu Lapis yang Berpotensi Menyebabkan Kecelakaan Kerja. In IENACO. Solo: Universitas Muhammadiyah Surakarta. Retrieved from https:// 
publikasiilmiah.ums.ac.id/handle/11617/ 8678

Saifudin, Munahar, S., \& Khusaeni, D. A. (2016). Perilaku inhibitor korosi pada radiator. Flywheel, II(November). Retrieved from http://jurnal.untirta.ac.id/ index.php/jwl/article/view/1360/1082

Saifudin, Sutoyo, Malau, V., \& Iswanto, P. T. (2015). Karakterisasi mekanis dan fisis lapisan diamond-like carbon (DLC) dengan teknik plasma assisted chemical vapor deposition (PACVD) pada permukaan tool steel HSS. In The 2nd URECOL (pp. 24-29). Semarang: Universitas Muhammadiyah Semarang.

Setiyo, M. (2017a). Listrik \& Elektronika Dasar Otomotif (Basic Automotive Electricity and Electronics). (A. Burhanudin, Ed.). Magelang: UNIMMA Press.

Setiyo, M. (2017b). Teknik Menyusun Manuskrip dan Publikasi Ilmiah Internasional. (B. Waluyo, Ed.). Yogyakarta: Deepublish.

Setiyo, M., \& Munahar, S. (2017). AFR and fuel cut-off modeling of LPG-fueled engine based on engine, transmission, and brake system using fuzzy logic controller (FLC). Journal of Mechatronics, Electrical Power, and Vehicular Technology, 8, 50-59. http://doi.org/10.14203/ j.mev.2017.v8.50-59

Setiyo, M., Munahar, S., Triwiyatno, A., \& Setiawan, J. D. (2017). Modeling of deceleration Fuel cut-off for LPG fuelled engine using Fuzzy logic controller. International Journal of Vehicle Structures and Systems, 9(4). http:// doi.org/10.4273/ijvss.9.4.12

Setiyo, M., Saifudin, Purnomo, B. C., Waluyo, B., \& Ramadhan, A. I. (2017). Temperature Distribution of R-134a
Through Aluminum and PTFE Expansion Valve on Automotive Air Conditioning Applications. ARPN Journal of Engineering and Applied Sciences, 12(4), 1046-1051. Retrieved from http:// www.arpnjournals.org/jeas / research_papers/rp_2017/ jeas_0217_5723.pdf

Setiyo, M., Soeparman, S., Hamidi, N., \& Wahyudi, S. (2016). Techno-economic analysis of liquid petroleum gas fueled vehicles as public transportation in Indonesia. International Journal of Energy Economics and Policy, 6(3), 495-500.

Setiyo, M., Soeparman, S., Hamidi, N., \& Wahyudi, S. (2017a). Characteristic of LPG compositions in the fuel line during discharging process. International Journal of Technology, 8(1). http:// doi.org/10.14716/ijtech.v8i1.4117

Setiyo, M., Soeparman, S., Hamidi, N., \& Wahyudi, S. (2017b). Cooling effect characteristics of a $1 / 2$ cycle refrigeration system on an LPG fuel system. International Journal of Refrigeration, 82. http://doi.org/10.1016/ j.ijrefrig.2017.06.009

Setiyo, M., Soeparman, S., Wahyudi, S., \& Hamidi, N. (2016). A simulation for predicting potential cooling effect on LPGfuelled vehicles. In AIP Conference Proceedings (Vol. 30002, p. 30002). American Institute of phisics. http://doi.org/ $10.1063 / 1.4943426$

Setiyo, M., Soeparman, S., Wahyudi, S., \& Hamidi, N. (2018). The Alternative Way to Drive the Automobile Air-Conditioning, Improve Performance, and Mitigate the High Temperature: ALiterature Overview. Periodica Polytechnica Transportation Engineering, 46(1), 36-41. http://doi.org/ https://doi.org/10.3311/PPtr.8892 
Setiyo, M., Waluyo, B., Anggono, W., \& Husni, M. (2016). Performance of Gasoline/LPG Bi-Fuel Engine of Manifold absolute Pressure Sensor (MAPS) Variations Feedback. ARPN Journal of Engineering and Applied Sciences, 11(7), 4707-4712. Retrieved from http:// www.arpnjournals.org/jeas/ research_papers/rp_2016/ jeas_0416_4012.pdf

Setiyo, M., Waluyo, B., Husni, M., \& Karmiadji, D. W. (2016). Characteristics of 1500 CC LPG fueled engine at various of mixer venturi area applied on Tesla A100 LPG vaporizer. Jurnal Teknologi. http://doi.org/10.11113/jt.v78.7661

Setiyo, M., Waluyo, B., Purnomo, B. C., Munahar, S., \& Setyawan, I. C. (2017). Studi Numerik/ : Efek Perubahan Komposisi LPG terhadap Energy Delivery pada Spark Ignition ( S . I .) Engine. In The 6th URECOL (pp. 17-20). Magelang: Universitas Muhammadiyah Magelang. Retrieved from http:// journal.ummgl.ac.id/index.php/urecol/ article/view/1534

Triwiyatno, A., Sinuraya, E. W., Setiawan, J. D., \& Munahar, S. (2016). Smart controller design of air to fuel ratio (AFR) and brake control system on gasoline engine. In ICITACEE 2015 - 2nd
International Conference on Information Technology, Computer, and Electrical Engineering (pp. 233-238). h t t p : // d o i .org/10.1109/ ICITACEE.2015.7437805

Waluyo, B., Condro, B., \& Saifudin, H. (2015). Penggunaan berbagai jenis filter pada oil catch tank untuk perbaikan performansi mesin old vehicle. In Semnastek (pp. 14). Jakarta: FAkultas Teknik Universitas Muhammadiyah Jakarta. Retrieved from https://jurnal.umj.ac.id/index.php/ semnastek/article/view/472

Waluyo, B., \& Saifudin. (2016). Performance of SI Engine at Various of Oil Catch Tank Filter Materials. International Journal of Innovative Research in Science, Engineering and Technology, 5(11), 18812-18818. http://doi.org/10.15680/ IJIRSET.2016.0511002

Waluyo, B., Wardana, I. N. G., Yuliati, L., \& Sasongko, M. N. (2018). The role of molecule cluster on the azeotrope and boiling points of isooctane-ethanol blend. Fuel, 215(September 2017), 178-186. http://doi.org/10.1016/j.fuel.2017.10.103

Widiyanto, A., \& Munahar, S. (2016). Keyless Automatic Lock System using RFID \& Smartphone. In ICETIA (pp. 5-11). Solo. 